УДК 575.224+577.21

\title{
STIMULATION OF NOGALAMYCINE PRODUCTION BY COEXPRESSION OF SNORA AND RELA GENES IN STREPTOMYCES NOGALATER LV 65
}

\author{
D. O. Klymyshyn \\ klymyshyn.d@gmail.com
}

Institute of Animal Biology NAAS, 34 Stus str., Lviv 79034, Ukraine, inenbiol@mail.lviv.ua

Danylo Halytsky Lviv National Medical University,

69 Pekarska str., Lviv 79010, Ukraine, office@meduniv.lviv.ua

Anthracycline antibiotics are an important group of anticancer compounds widely used in tumor chemotherapy. They are used to treat different types of diseases such as leukemias, lymphomas, breast, uterine, ovarian and lung cancers. Investigation of the regulatory mechanisms of antibiotic production in Streptomyces is of great interest, as these data provide a potential platform for generation of industrially important strains to increase the production of their secondary metabolites. Streptomyces nogalater Lv65 is a producer of an anthracycline antibiotic nogalamycine. Derivatives of this antibiotic are used in chemotherapy of tumors. Here we focused on expression of snorA and relA genes in S. nogalater Lv65. A set of plasmids for the expression of snorA and relA genes were generated. Conjugation procedures of the S. nogalater Lv65 and UV33, S. echinatus and S. peucetius wild-type strains with $p K C A I I$ and $p V W B A 1$ were carried out from E. coli ET12567 ( $p$ UB307). An increasing in the nogalamycin production was observed when $p K C A I I$ and $p$ VWBA1 plasmids were introduced into the Lv65 and UV33 strains. We believe that this indicates a crucial role for snorA and relA in nogalamycin biosynthesis under some nutritional conditions. This is in agreement with the general knowledge about aforementioned regulatory genes. Expression of snorA and relA genes in S. echinatus Lv 22 and S. peucetius subsp. caesius - producers of aranciamycine and doxorubicin respectively, stimulates antibiotic production in the above strains.

Keywords: ANTIBIOTIC BIOSYNTHESIS, STREPTOMYCES NOGALATER, NOGALAMYCINE, SARP PROTEINS

\section{СИНТЕЗ НОГАЛАМІЦИНУ ЗА УМОВ КОЕКСПРЕСIÏ ГЕНIВ SNORA TA RELA B STREPTOMYCES NOGALATER LV 65}

\author{
Д. О. Климишин \\ klymyshyn.d@gmail.com
}

Інститут біології тварин НААН,

вул. Стуса 34, м. Львів, 79034, Україна, inenbiol@mail.lviv.ua

Львівський національний медичний університет імені Данила Галицького,

вул. Пекарська, 69, м. Львів, 79010, Україна, office@meduniv.lviv.ua

Антрациклінові антибіотики є групою протипухлинних сполук, щзо широко використовуються в хіміотерапї ракових захворювань. Вони використовуються для лікування низки захворювань, таких як лейкози, лімфоми, рак матки, яєчників, а також раку легень. Дослідження регуляторних механізмів синтезу антибіотиків у стрептоміцетів є важливою проблемою сучасної мікробіологї̈ та біотехнологї. Ці дані дають потениійну платформу для одержання промислово важливих итамів бактерій, щзо дозволяє збільшити виробництво їхніх вторинних метаболітів. Streptomyces nogalater Lv65 є продуичентом антрацчикінового антибіотика ногаламіццин. Хімічні модифікації изього антибіотика сьогодні використовуються в хіміотерапії ракових захворювань. Робота присвячена експресії генів snorA i relA у клітинах $S$. nogalater. Сконструйовано низку плазмідних молекул ДНК для експресії генів snorA i relA, шзо є задіяними у регуляції вторинного метаболізму у актиноміцетів. Плазміди рКСАII та рVWBA1 перенесені в клітини штамів S. nogalater Lv65 та UV33, а також штамів S. есhinatus ma S. peисеtius із використанням міжродової кон'югації з E. coli ET12567 (pUB307).За умов коекспресї̈ 
регуляторних генів у складі олігокопійної плазміди рКСАII та інтегративної рVWBA1 спостерігається зростання синтезу ногаламіцину в штамах Lv65 та UV33. Очевидно, щео це вказує на важливу роль генів snorA $i$ relA у біосинтезі ногаламіціну за культиваційних умов представлених досліджень та узгоджується із загальними уявленнями про їхню участь у регуляції вторинного метаболізму у актиноміцетів. Гетерологічна експресія snorA i relA у складі рKCAII та pVWBA1 в клітинах S. echinatus LV 22 ma S. peисеtius subsp. саеsius підвищує продукцію аранциаміцину та доксорубіцину, відповідно.

\author{
Ключові слова: БІОСИНТЕЗ АНТИБІОТИКІВ, STREPTOMYCES NOGALATER, НОГАЛА- \\ МІЦИН, SARР-БІЛКИ
}

\title{
СТИМУЛИРОВАНИЕ ПРОДУКЦИИ НОГАЛАМИЦИНА ПУТЕМ КОЕКСПРЕСИИ ГЕНОВ SNORA И RELA У STREPTOMYCES NOGALATER LV 65
}

\author{
Д. О.Климишин \\ klymyshyn.d@gmail.com
}

Институт биологии животных НААН, ул. Стуса 34, г. Львов, 79034, Украина, inenbiol@mail.lviv.ua

Львовский национальный университет имени Данила Галицкого, ул. Пекарская, 69, г. Львов, 79010, Украина, office@meduniv.lviv.ua

\begin{abstract}
Антрациклиновые антибиотики являются важной группой противоопухолевых соединений, широко используемых в химиотерапии опухолей. Они используются для лечения различных видов заболеваний, таких как лейкозы, лимфомы, рака матки, яичников, а также легких. Исследование регуляторных механизмов биосинтеза антибиотиков у Streptomyces представляет научный интерес, так как эти данные дают потенциальную платформу для получения промышленно важных штаммов, что позволяет увеличить производство их вторичных метаболитов. Streptomyces nogalater Lv65 является продуцентом антрациклинового антибиотика ногаламицина. Химические модификаиии этого антибиотика сегодня широко используются в химиотерапии опухолевых заболеваний. Данная работа сосредоточена на коэкспрессии генов snorA и relA в клетках S. nogalater Lv65. B работе получены плазмиды рКСАII и рVWBAI для экспрессии регуляторных генов. Плазмиды рКСАII и pVWBA1 доставлены в клетки штаммов S. nogalater Lv65 и UV33, а также штаммов S. есhinatus u S. peисеtius с использованием междуродовой конъюгачии из E. coli ET12567 (pUB307). Перенос этих векторов в клетки штаммов $S$ nоgalater Lv65 и UV33 активировал продукиию ими ногаламицина. Очевидно, что это указывает на важную роль snorA и relA в регуляции биосинтеза ногаламицина в условиях культивирования, представленных в этой работе. Это согласуется с общими знаниями о вышеупомянутых регуляторных генах. Гетерологическая коэкспрессия генов snorA и relA в клетках $S$. echinatus LV 22 u S. peисеtius subsp. саеsius стимулировала продукцию аранциамицина и доксорубицина соответственно.
\end{abstract}

\section{Ключевые слова: БИОСИНТЕЗ АНТИБИОТИКОВ, STREPTOMYCES NOGALATER, НОГАЛАМИЦИН, SАRР-БЕЛКИ}

Mycelial bacteria of the genus Streptomyces are important subjects of modern microbiology and industrial biotechnology, primarily as producers of the majority of known antibiotics [1]. Antibiotic biosynthesis is controlled by many regulatory elements at different levels. Most of the antibiotics are produced by complex biosynthetic pathways encoded by clustered genes [1,2]. The gene clusters are usually regulated by pathwayspecific transcriptional regulators that are located in these clusters. In addition, various global regulatory genes have been identified, which affect antibiotic production indirectly and have pleiotropic roles in stress response and morphological differentiation [1]. Most of these pleiotropic regulatory genes have been shown to influence the activity of the pathway-specific regulatory genes. Expression of both types of regulatory gene is influenced by a variety of physiological and environmental factors, including growth rate, signaling molecules, 
imbalances in metabolism and various physiological stresses [1].

The final decision about onset of antibiotic production is made by transcriptional factors which genes are clustered with the respective antibiotic biosynthesis genes [3]. Members of this big group of proteins resemble the OmpR transcriptional regulator of Escherichia coli phosphate regulon particularly in the region of DNA-binding domain formed by "winged" helix-turn-helix structure [1-3]. Therefore, these transcriptional factors were grouped into SARP family [1]. SARP genes were found within almost all biosynthesis gene clusters governing aromatic polyketides production. These genes are usually clustered with antibiotic biosynthesis genes and activate or repress their expression. Manipulations of the SARP genes and pleiotropic regulatory genes have been shown to increase the production of antibiotics by streptomycetes [1, 3-5, 6].

Streptomyces nogalater Lv65 is a producer of an anthracycline antibiotic nogalamycin [4]. Derivatives of this antibiotic are used in chemotherapy of tumors. Among anthracycline derivatives, nogalamycines showed superior cytotoxicity and antitumor activity and also proved to be effective against breast cancer clinically [4]. Certain aspects of the regulation of nogalamycin production have been characterized [7-13].

The goal of the present work is coexpression of snor $A$ and relA genes in $S$. nogalater Lv65. We expect that manipulations with these regulators will provide a potential platform for manipulating with industrially important strains to increase production of their secondary metabolites.

\section{Materials and methods}

Streptomyces nogalater Lv65, nogalamycine producer, was used as a source of chromosomal DNA. Growth was carried out on trypticase soya broth (TSB; Oxoid) or R5A medium [14]. Spores of Streptomyces strains were harvested from a sporulated lawn grown on oatmeal agar plates [15]. The Streptomyces and $E$. coli strains and plasmids used in the present work are described in Table 1.
Apramycin-resistant, strains were tested for loss of apramycin resistance by culturing the colonies on HA plates with and without apramycin. Resistant colonies were subjected to Southern blotting.

Escherichia coli was grown in LuriaBertani (LB) medium at $37^{\circ} \mathrm{C}$, and plasmids were introduced into $E$. coli by transformation done by standard procedures [15]. pBluescriptKS was purchased from Amersham Biosciences. pVWB, a non-replicative vector carrying an apramycin resistance deteminant, was described by Bierman et al. [15]. For $E$. coli strains harboring plasmids, ampicillin was added at a final concentration of 100 $\mathrm{mg} / \mathrm{ml}$. Antibiotic activity of $S$. nogalater strains was studied by diffusion in agar using Sarcina lutea as a test-culture. $S$. nogalater strains were grown in liquid SG medium and the antibiotics were extracted from the culture liquid by chloroform $(1: 1)$. The extracts were dried at $37^{\circ} \mathrm{C}$, the dry residue was dissolved in methanol, and applied to petri dishes with $0.7 \%$ agar containing Sarcina lutea (109 CFU). The plates were incubated at $28^{\circ} \mathrm{C}$ for 12 and $72 \mathrm{~h}$. Strain productivity was evaluated by the ratio between the diameter of Sarcina lutea growth inhibition zone to the dry mass of the mycelium from which the antibiotic was extracted.

Conjugation procedures of the $S$. nogalater, S. echinatus and S. peucetius wildtype strains with pKCAII and pVWBA1 was carried out from E. coli ET12567 (pUB307) as described [16]. Donor E. coli ET12567 (pUB307) strain was grown on LB agar supplemented with apramycin $(50 \mu \mathrm{g} / \mathrm{mL})$ and kanamycin $(50 \mu \mathrm{g} / \mathrm{mL})$ for $12 \mathrm{~h}$ at $37^{\circ} \mathrm{C} . S$. nogalater spore suspension (harvested from 7 days-old lawn), according to a standard protocol, was heat-treated for $10 \mathrm{~min}$ at $50{ }^{\circ} \mathrm{C}$. Donor and recipient cells were mixed in a 1:1 ratio and spread on oatmeal medium. The plates were incubated $\left(12 \mathrm{~h}, 28{ }^{\circ} \mathrm{C}\right)$ and then covered with $1 \mathrm{ml}$ of water containing $1.5 \mathrm{mg}$ of apramycin and $1.5 \mathrm{mg}$ of nalidixic acid. Transconjugants were counted after 5 days. The frequency of transconjugant occurrence was calculated as a ratio of the number of transconjugants to the titer of recipient strain spores. 
Standard methods for DNA isolation and manipulation were performed as described by [15]. Genomic DNA was isolated from Streptomyces strains by lysozyme treatment and phenol/chloroform extraction as described elsewhere [14].

Thin layer chromatography (TLC) of the antibiotic extracts was performed on Silufol UV254 silica gel plates in the solvent system chloroform-methanol-ethanol-distilled water
$(120: 25: 6: 4.5)$. Detection of antibiotics on the plates was performed under visible and ultraviolet light $(\lambda 254 \mathrm{~nm})$.

Southern blot analysis was performed on Hybond-N membranes (Amersham Biosciences) with digoxigenin-labelled probes by using DIG high prime DNA labelling and detection kit II (Roche Molecular Biochemicals) [15]. Hybridization filters were washed off under standard conditions.

Table 1

\section{Strains and plasmids}

\begin{tabular}{|c|c|c|}
\hline $\begin{array}{l}\text { Bacterial strain } \\
\text { or plasmid }\end{array}$ & Description & Source or reference \\
\hline E. coli $\mathrm{DH} 5 \alpha$ & $\begin{array}{l}\text { supE44 } \Delta \text { lacU169( } \varphi 80 \text { lacZAM15) hsdR17 } \\
\text { recAlendA1gyrA96 thi-1 relA1 }\end{array}$ & MBI Fermentas \\
\hline $\begin{array}{l}\text { E. coli ET12567 } \\
\text { (pUB307) }\end{array}$ & dam-13::Tn9 $\left(\mathrm{Cml}^{\mathrm{r}}\right) d c m-6$ hsdM & $\begin{array}{l}\text { Microbial culture collection of antibiotic } \\
\text { producers, Lviv, Ukraine }\end{array}$ \\
\hline $\begin{array}{l}\text { S. echinatus Lv } 22 \\
(=\mathrm{DSM} 40730)\end{array}$ & Producer of aranciamycin & The same \\
\hline S. nogalater Lv 65 & Producer of nogalamycin & The same \\
\hline $\begin{array}{l}\text { S. peucetius subsp. } \\
\text { Caesius }\end{array}$ & Producer of doxorubicin & The same \\
\hline pVWB & $\begin{array}{l}\text { E. coli/Streptomyces shuttle vector with } \varphi \mathrm{BT} 1 \\
\text { attP/int integrative system, aac(3)IV }\end{array}$ & $\begin{array}{l}\text { Microbial culture collection of antibiotic } \\
\text { producers, Lviv, Ukraine }\end{array}$ \\
\hline pVWBA1 & $\begin{array}{l}\text { pVWB derivative harboring snor } A \text { and relA } \\
\text { genes cloned in the EcoRI, aac(3)IV }\end{array}$ & This work \\
\hline pKC1218E & $\begin{array}{l}\text { E. coli/Streptomyces shuttle expression vector } \\
\text { with PermE and SCP2 replicon, aac(3)IV }\end{array}$ & {$[15]$} \\
\hline pKCAII & $\begin{array}{l}\text { pKC1218E derivative with a fragment harboring } \\
\text { SnorA and relA genes gene, aac }(3) I V\end{array}$ & This work \\
\hline
\end{tabular}

\section{Results and discussion}

Previously, we have studied the effect of additional copies of the snorA gene on nogalamycin synthesis in S. nogalater Lv65. Nogalamycin production was increased after insertion of the additional copies of the snorA gene (at least under our experimental conditions) $[5,6]$. relA $(S$. coelicolar A3(2)) also stimulates antibiotic production in $S$. nogalater. In the present study snor $A$ and relA genes were simultaneously coexpressed in the pKC1218based plasmid pKC1218E under constitute ErmEp promoter and in the inegrative plasmid pVWB.

Approximately, $1.7 \mathrm{~kb}$ fragment carrying the entire relA gene and its flanking regions were cloned from [5]. The product was cloned into EcoRV site of pKCEAII to give pKCAII (Fig. 1a). The obtained construct contains snorA and relA genes controlled by ErmEp of Saccharapolyspora erytreae. Five $\mathrm{Am}^{\mathrm{r}}$ transconjugants (an indicative of a pKCEAII) were selected out of 17 tested. All seven candidates exhibited the same phenotype. One of them (referred to as pKCEAII ${ }^{+}$) was used throughout this work.

Integrative vector for snorA and relA genes overexpression was generated as follows. A $2.4 \mathrm{~kb}$ fragment carrying the entire snorA gene and its promoter regions was cloned from $\mathrm{pKCEA}$ to give $\mathrm{pVWBA}$. This plasmid was used as a DNA source for construction of pVWBA1 (Fig. 1b). The relA gene was 

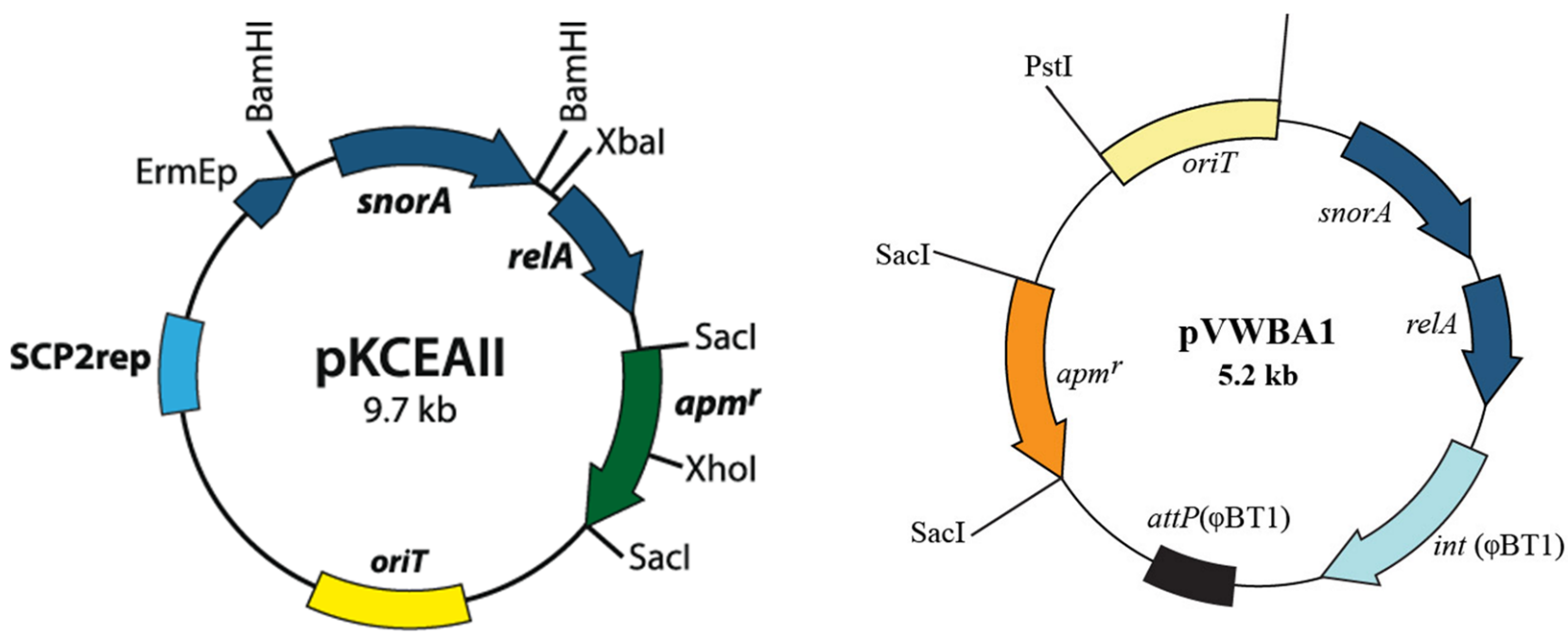

Fig. 1. Structure of pKCAII and pVWBA1 plasmids

introduced into the unique BamHI site within pVWBA. Obtained vector was transferred into streptomycetes using intergeneric conjugation from $E$. coli $\mathrm{ET}$ 12567. Two Am ${ }^{\mathrm{r}}$ colonies (an indicative of a $p$ VWBA1) were selected. One of them (referred to as $\mathrm{pVWBA}^{+}$) was used throughout this work.

Both pKCEAII ${ }^{+}$and pVWBA1 plasmids were transferred to $S$. nogalater Lv65 (wild-type straine) and $S$. nogalater UV33 (UV-induced overproducer of nogalamycin). Expression of
snorA and relA genes in pKCEAII ${ }^{+}$increase the nogalamycin production in the following strains (Fig. 2). We believe that this indicates a crucial role for snor $A$ and relA in nogalamycin biosynthesis under some nutritional conditions. This is in agreement with the general knowledge about aforementioned regulatory genes. Manipulations of the SARP genes and relA have been shown to increase the production of antibiotics by streptomycetes. For example, introduction of lanI (SARP
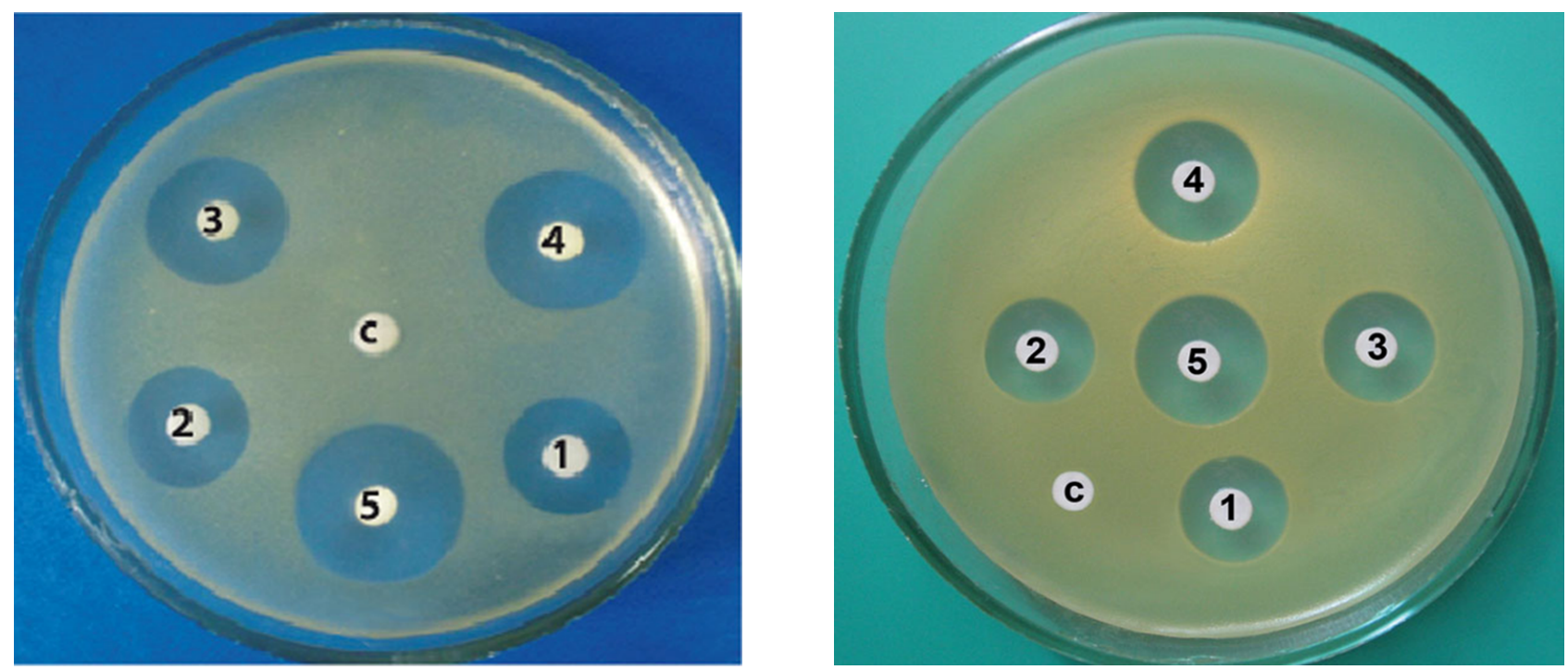

Fig. 2. a. Growth inhibition zones of the $S$. lutea test culture caused by the antibiotic extracts obtained from strains Lv65 (1), pKC1218E (2), UV33 (3), $\operatorname{Lv65~pKCEAII~}^{+}(4), \mathrm{UV} 33_{\text {pKCEAII }}^{+}(5)$, $\mathrm{c}$ - negative control (methanol, used as a solvent). The antibiotics were extracted from equal amounts of wet biomass. $b$. Growth inhibition zones of the $S$. lutea test culture caused by the antibiotic extracts obtained from strains Lv65 (1), $\mathrm{pVWB}^{+}$(2), Lv65 pVWBA1 ${ }^{+}$(3), UV33 (4), UV33 pVWBA1 ${ }^{+}(5), \mathrm{c}$ - negative control (methanol, used as a solvent) 
regulator of landomycin A biosynthesis in $S$. cyanogenus S136) and IndI (lanI homologue controlling landomycin E biosynthesis in $S$. globisporus 1912) activated production of aforementioned antibiotics [3].

Accumulation of ppGpp in streptomyces also causes the induction of complex changes in the pattern of gene expression with global cellular consequences. For example, in $S$. coelicolor, genetically the most characterized streptomycete that serves as a model organism for the genus, accumulation of ppGpp occurs transiently in response to amino acid limitation and requires the presence of both RelA and RelC [17-18].

Nogalamycine biosynthesis was also increased in $S$. nogalater Lv65 and $S$. nogalater UV33 strains harboring pVWBA1. pVWBA1 contains int gene of VWB phage which inegrates site-specifically into two sites of $S$. nogalater chromosome. Site-specific integration makes pVWBA1 a powerful tool for generation of stable overproducers of nogalamycin.

pVWBA1 and pKCAII were used for the coexpression of snorA and relA genes in heterological hosts. S. echinatus Lv 22 and S. peucetius subsp. caesius - producers of aranciamycine and doxorubicin respectively, were used in the present study. Both plasmids were transferred into $S$. echinatus and $S$. peucetius cells using intergeneric conjugation from E. coli ET 12567 (pUB307). Stimulation of aranciamycine and doxorubicin production was observed in $\mathrm{pVWBA}^{+}$and $\mathrm{pKCAII}^{+}$ strains.

\section{Conclusions}

Here we further investigated the possibilities of nogalamycine overproduction by combination of SARP and pleiotropic regulatory genes cloned in multy-copied and integrative vectors. Expression of snorA and relA genes cloned in $\mathrm{pKCEAII}^{+}$and pVWBA1 plasmids increase the nogalamycin production in $S$. nogalater strains. Both genes also stimulate aranciamycine and doxorubicin production in S. echinatus and S. peucetius. Our experiments provide a potential platform for manipulating anthracycline producing streptomycetes to increase production of their secondary metabolites.

Prospects for further research. Understanding of the physiological and environmental conditions that trigger the expression of the snorA and relA genes, or that influence the activities of their products, and the corresponding signal transduction pathways that are responsible for the activation of secondary metabolism remains a main goal for the future research.

1. Bibb M. J. Regulation of secondary metabolism in Streptomyces. Microbiology, 2005, 8, pp. 208-215.

2. Wezel G., McDowall K. The regulation of second metabolism of Streptomyces: new links and experimental advances. Nat. Prod. Rep., 2011, 28, pp. 1311-1333.

3. Rebets Y., Dutko L., Ostash B., Luzhetskyy A., Kulachkovskyy O., Yamaguchi T., Nakamura T., Bechthold A., Fedorenko V. Function of lanI in regulation of landomycin A biosynthesis in Streptomyces cyanogenus S136 and cross-complementation studies with Streptomyces antibiotic regulatory proteins encoding genes. Arch. Microbiol., 2008, 189, pp. 111-120.

4. Klymyshin D., Gromyko O., Gren T., Nymets O., Honchar M., Fedorenko V. Chemistry and biology of nogalamycins, Visnyk of Lviv Univ. Biology series, 2010, vol. 54, pp. 15-26 (in Ukrainian).

5. Klimishin D., Rabyk M., Gren T., Nimets O. and Fedorenko V. Construction of Streptomyces nogalater Lv65 strains with enhanced nogalamicin biosynthesis using regulatory genes. Appl. Biochem. Microbiol., 2011, 47, (6), pp. 594-598.

6. Klymyshin D., Gren T. and Fedorenko $\mathrm{V}$. Role of the snorA gene in Streptomyces nogalater Lv65 biosynthesis. Microbiology, 2011, 80, (4), pp. 496-501.

7. Klymyshyn D.O., Gromyko O.M., Fedorenko V.O. Cloning and heterological expression of Streptomyces nogalater IMET43360 O-methyltransferase genes, involved in nogalamycin biosynthesis, The Bulletin of Vavilov Society of Geneticists and Breeders of Ukraine, 2008, vol. 6, №2, pp. 224232 (in Ukrainian). 
8. Klimishin D., Rabyk M. and Fedorenko $\mathrm{V}$. Methylation of nogalose during nogalomycin biosynthesis by Streptomyces nogalater Lv65. Microbiology, 2013, 82, (2), pp. 162-168.

9. Klymyshin D., Stefanyshyn O., Fedorenko V. Role of genes snoaM, snoaL, and snoaE in the biosynthesis of nogalamycin in Streptomyces nogalater Lv65. Cytology and Genetics, 2015, 49, (3), pp. 152-157.

10. Klymyshyn D., Gren T., Fedorenko V. Cloning and investigation of snorA gene, a putative positive regulator of nogalamycin biosynthesis in Streptomyces nogalater, Visnyk of Lviv Univ. Biology series, 2009, vol. 50, pp. 3-10 (in Ukrainian).

11. Klymyshin D., Nimets O., Stefanyshyn O. and Fedorenko V. Heterologous expression of the lndYR and $w_{b l A_{\mathrm{gh}}}$ genes in Streptomyces nogalater LV65, S. echinatus DSM40730, and S. peucetius subsp. Caesius ATCC27952 (producers of anthracycline antibiotics). Cytology and Genetics, 2013, 47, (4), pp. 197201.

12.Klymyshin D., HoncharM., Stefanyshyn O., Fedorenko V. A gene cloning system for the aranciamycin producer strain Streptomyces echinatus Lv 22. Microbiology, 2014, 83, (12), 119-124.

13. Klymyshin D., Gren T., Fedorenko V. Investigation of snogL gene, involved in nogalamycin biosynthesis in Streptomyces nogalater IMET43360, Visnyk of Lviv Univ. Biology series, 2010, vol. 52, pp. 30-35 (in Ukrainian).

14. Aravitska O., Klymyshin D., Gromyko O., Fedorenko V. Obtaining and transformation of Streptomyces nogalater IMET43360 protoplasts', Visnyk of Lviv Univ. Biology series, 2008, vol. 48, 69-74 (in Ukrainian).

15. Kieser T., Bibb M., Buttner M., Chater K. and Hopwood D. Practical Streptromyces genetics, John Innes Foundation, Norwich, $2000.630 \mathrm{p}$.

16. Klymyshyn D.O., Gromyko O.M., Fedorenko V.O. Application of intergeneric conjugation of Escherichia coli-Streptomyces for transfer of recombinant DNA into the strain S. nogalater IMET43360, Cytology and Genetics, 2007, 41 (5), pp. 263-267.

17. Gomez-Escribano J., Martin J., Hesketh A., Bibb M., Liras P. Streptomyces clavuligerus relA null mutants overproduce clavulanic acid and cephamycin $\mathrm{C}$ : negatine regulation of secondary metabolism by (p)ppGpp. Microbiology, 2008, 154, pp. 744-755.

18. Hesketh A., Sun J., Bibb M. Induction of ppGpp synthesis in Streptomyces coelicolor A3(2) grown under conditions of nutritional sufficiency elicits actII-ORF4 transcription and actinorhodin biosynthesis. Molecular Microbiology, 2001, 39, (1), 136-144. 